\title{
The Oldest Addiction Treatment Institution on the Historical Territory of Slovakia: The Istebné nad Oravou Treatment Facility (1937-1949)
}

\author{
ŠEJVL, J., MAŠLÁNIOVÁ, M., MIOVSKÝ, M.
}

Charles University and General University Hospital in Prague, First Faculty of Medicine, Department of Addictology, Prague, Czech Republic
Citation | Šejvl, J., Mašlániová, M., Miovský, M. (2019). The Oldest Addiction Treatment Institution on the Historical Territory of Slovakia: The Istebné nad Oravou Treatment Facility (1937-1949). Adiktologie, 19(1), 17-25; https://doi.org/10.35198/01-2019-001-0002
BACKGROUND: There is a continuous tradition of institutional impatient addiction treatment in what is now the Czech Republic which dates back to 1948, when the "Apolinar Model" began to be developed by Jaroslav Skála and his colleagues. Before the advent of this treatment approach, there was only one inpatient facility providing addiction treatment on the historical territory of Slovakia, the institution in Istebné nad Oravou (1937-1949). AIMS: To explore the modern history of anti-alcohol activities developed in the first half of the 20th century in Slovakia and the origin, operation, and dissolution of the first specialised inpatient addiction treatment facility. METHODS: Qualitative content analysis of available historical documents was used to collect the data. The documents were categorised according to their relevance to the focus of the research, taking into account the site under consideration, the time and place of its establishment, and the roles of the people involved. RESULTS AND CONCLUSION: The establishment of the first institutional treatment facility on the historic territory of Slovakia was marked by some specific features ensuing from the relative lack of interest in dealing with addictionrelated issues on the part of society. This was reflected in the circumstances of its origin, funding, and occupancy, in operational reductions following the proclamation of the independent Slovak State (1939), and in the gradual dissolution of the facility in 1949. In spite of all this, the Istebné nad Oravou facility was a significant milestone in institutional addiction treatment in Slovakia.

\section{Keywords | Istebné nad Oravou - Alcohol Dependency - History of Treatment - Treatment Programme - Institutional Treatment - Alcoholism - Morphinism - Cocainism}




\section{INTRODUCTION}

The origins of the present-day treatment approach to people dependent on alcohol in Slovakia (we will use the phrases "on the historical territory of Slovakia" or "in what is now Slovakia" throughout the text to avoid misunderstanding) can be traced back to the activities developed in the mid-19 ${ }^{\text {th }}$ century as part of the temperance movement and awareness-raising (preventive) efforts. To a great extent, concerns about alcohol-related issues and abstinence-oriented initiatives resulted from social changes which occurred at the time and which were brought about by political and social developments in Slovakia. These changes in the perception of alcohol ensued from the activities of the Štúr Movement and the representatives of the Roman Catholic Church, who, being aware of the health, economic, and social consequences of the excessive consumption of alcohol, especially spirits, also supported sobriety associations.

This does not mean that problems related to excessive drinking had not occurred until that period. Antonín Mareš suggests that the history of alcoholism in what is now Slovakia can be divided into the earlier and later stages. While the earlier stage mainly involved the manufacturing and use of home-made wine, beer, and fermented juices, traded until the $12^{\text {th }}$ century, the later phase of alcoholism-related issues was associated with the manufacturing and use of spirits (Mareš, 1981). The Slovak national movement, spearheaded by L'udovít Štúr and Samo Chalupka, to name its most prominent personalities, drew attention to this issue especially in terms of the health of the nation and the economic situation of the families affected by alcoholism which experienced its immediate consequences as they struggled for their very existence. The social situation between 1844 and 1874 was very difficult: the population was tormented by subsistence problems, on the verge of famine in some cases, and many saw resorting to alcohol as the only solution (Sedlák, 1998).

The history of sobriety initiatives in Slovakia, or, to be accurate, records of alcohol-related issues, dates back to much earlier times. Ottmar Gergelyi reports that the first spirits were brought to Bratislava from Vienna in 1439. By the mid-16 ${ }^{\text {th }}$ century beer was becoming popular too (Gergelyi, 1973). In the same period the first temperance associations came into existence in Europe. ${ }^{1}$ In 1517 Sigismund of Dietrichstein established the Order of Saint Christopher in the Holy Roman Empire of the German Nation. ${ }^{2}$ At the end of the $16^{\text {th }}$ century two major works by Johannes Bocatius were published in Bardějov. In the first of them, Castra temperantiae vel Exercitia Poetica, quae Lepidis aliquot et festivis eppigrammatis crapulam, Eribretatem, potationem et vicina vitia oppugnant, detestentur et ejurant (1597), Bocatius provided descriptions of alcoholic figures (types) from his social environment (a man ailing as a result of alcohol, a drunken woman, a judge who is a drunkard, a priest who suffers

1 With the exception of a temperance association established as early as during the reign of Emperor Fridrich III. (1415-1493).

2| Habsburg possessions in Central Europe from a hangover while delivering a sermon, drunken poets and teachers, a man who "has a lot of cups but few books", etc.) spiked with satirical remarks (Duka - Zólyomi, 2015). The second publication was named Hungaridos, Libri Poematum $V$. (1599). At the beginning of the $17^{\text {th }}$ century, in central Germany, Maurice, Landgrave of Hesse, founded the Order of Temperance, the members of which were not allowed to drink more than seven tumblers while dining (Gergelyi, 1973; Duka - Zólyomi, 2015). As regards European teetotal initiatives, a salient breakthrough is associated with Theobald Mathew (Father Mathew), an Irish Catholic priest, who established an abstinence movement in Ireland in April 1838. Between 1845 and 1849 this movement enrolled about three million people, which represented more than half of the adult population of Ireland at the time (Winskill, 1892; Chisholm, 1911). From there, the notion of temperance and abstinence spread to the Continent and influenced the development of anti-alcohol movements and the establishment of institutional addiction treatment facilities. The first temperance society on the territory of what is now Slovakia was founded by the teacher Jan Kadavý in Pressburg (today's Bratislava) on $11^{\text {th }}$ November 1844. In the same year, a temperance society was established in Nižné Ružbachy. Subsequently, temperance associations came into existence in Medzilaborce and Levoča. Other such organisations, such as that in Divina (in the Žilina region), were established by Štefan Závodník (Gergelyi, 1973). Major sources of relevant information included "Orol Tatránsky", a supplement to the Slovak National Newspaper published by Štúr.

The historical territory of what is now Slovakia faced a growing problem with the excessive use and homemade distilling of spirits. A "pot still" became an integral part of the inventory of farmsteads and the motto "You eat, you learn, you drink, you enjoy, and the Devil knows what will become of what is left of you" was adhered to by many (Jurkovič et al., 1935). The knowledge and skill of makeshift distilling added a new dimension to the issue of excessive alcohol use - potatoes, which were easily available, were used to make homemade spirits. This caused the manufacturing and related consumption of spirits to spiral out of control, making it necessary for the public authorities to step in and try to address the problem. At the beginning of the $17^{\text {th }}$ century various statutory decrees to restrict excessive drinking were issued.

\section{METHODOLOGY}

The format of a simple case study of a specialised institution was used to conduct the content analysis. Primarily, basic key words were used to determine the universe (Ferjenčík, 2010) and the general search engine Google Scholar, as well as the specialised databases Kramerius, EBSCO, Electronic Journals Library Charles University (Institute of Scientific Information), and SALIS, was used to conduct the search. Subsequently, relevant historical sources were identified and three rounds of a basic review and archival research were performed. These steps were followed by the digital 
processing and classification, sorting, description, and categorisation of the sources that were identified. The following criteria were applied to make the general categorisation: i) the location where the product was obtained, ii) the topic which it relates to, iii) its time of origin, iv) its place of origin, and v) its author. Other general categories were constructed according to the nature of the product: i) texts, ii) products other than texts, and iii) photographs, in relation to the treatment facility in Istebné nad Oravou and to institutional addiction treatment in general. The categorisation was followed by content analysis (cf. Miovský, 2006, pp. 98-103). Our content analysis followed the approach reported by Plichtová (1996, pp. 311-313), with individual procedures being divided into interlinked stages. It involved various simple methods described by Miles and Huberman (1994), including the pattern recognition method. Similar methodological approaches were applied to our previously published studies on the specialised alcohol treatment institutions in Velké Kunčice (Šejvl \& Miovský, 2017, pp. 134-146) and Tuchlov (Šejvl \& Miovský, 2018, pp. 97-104).

\section{SLOVAK TEMPERANCE MOVEMENTS OF THE FIRST HALF OF THE $20^{\text {TH }}$ CENTURY}

In the whole of Europe, the beginning of the $20^{\text {th }}$ century was marked by anti-alcohol campaigns and criticism of insobriety and drinkers. In particular, efforts to disseminate teetotal attitudes and idealistic notions of nationwide abstinence involved the communication of messages about the risks of alcohol and alcoholism. Such messages included information presented in the regular print media - Rodina a škola (1901), Pokrok (1904), Národný hlásnik (1904), Krestan (1912), and Dolnozemský Slovák (1913) - often featuring fragmentary and inconsistent accounts of the risks posed by alcohol and its consequences and promoting total abstinence, but also specialist scholarly publications (also available in Hungarian: e.g. Fülöp, 1903), intended for both professionals, especially physicians, teachers, and the clergy, and the lay public.

In Austria-Hungary, alcohol use was a pressing issue even before the Great War (cf. e.g. Beneš, 1915), but the problem increased significantly with the outbreak of the First World War and its implications for society and people's quality of life. In addition to aggravating the dismal social situation in Slovakia at that time, particularly in rural areas, the war caused family traumas for which those who were affected seemed to find no other cure than alcohol. The high level of production and consumption of alcohol that already existed before the war continued to grow in the post-war period because of the abundant supply of basic materials. Legal measures adopted by the newly-established republic were only aimed at restricting the availability of alcohol, causing the cost of spirits to rise and thus spurring their homemade manufacturing. For example, a guide to a simple and efficient way of distilling home-made spirits was provided by Szeszfözés gyümölcsökböl borból és a borkészités melléktermékeiből (Zsigmond, 1906), a publication which became widely popular.

\section{1 "The First Republic" in Slovakia - Legal Background}

While in Bohemia and Moravia, the alcohol use situation did not cause any extraordinary concern, Slovakia and Carpathian Ruthenia faced much graver difficulties in this respect.

The legal regulations governing the sale and serving of alcohol in the initial years of the republic drew on the Austro-Hungarian laws. The pivotal piece of legislation was Act No. 68/1870 of the Imperial Criminal Code, providing for the organisation of the public health service. With reference to Section 17 of this law, a regulation ${ }^{3}$ was adopted on 19 December 1919, on the basis of which a permanent advisory board for tackling alcoholism was established as part of the Ministry of Public Health and Physical Education. The task of the advisory board was to deliver expert reports and proposals when requested to do so by the Ministry of Public Health and Physical Education, as well as proposing effective measures aimed at addressing alcoholism on its own initiative.

The law of 10 December $1918^{4}$ on special transitional provisions in Slovakia turned out to be a problematic regulation. Under Section 11, it stipulated that "all the rights granted for the manufacturing, tapping, and sale of all types of spirits shall be subject to revision and may be revoked. Any tapping of beverages other than beer and wine is prohibited in the meantime." While prohibiting the tapping of spirits, this restriction did not apply to their sale in bottles. This meant a great potential market for the Bohemian and Moravian distilling industry. At the same time, hazardous patterns of consumption of spirits were on the rise, making it obvious that alcohol users were not going to abstain. Jančík (2014) reported that the lack of alcohol led to the consumption of ether and denatured alcohol. Pot stills continued to be standard home equipment and a significant proportion of the population continued to engage in home distilling. In consequence, this led to an increase in the illegal importation of ethyl alcohol into Slovakia. None of the restrictive measures were in any way effective at reducing the consumption of spirits in Slovakia or illicit dealing in ethyl alcohol. The stipulation under consideration remained in operation until 3 July 1929, when it was annulled by Act No. 96/1929 Coll.

One of the most significant legal regulations during the Czechoslovak "First Republic" aimed at controlling the sale and serving of alcoholic beverages became known as the Holitscher ${ }^{5}$ Act (Lex Holitscher ${ }^{6}$ ). Coming into force on

3 | Regulation of the Government of the Republic of Czechoslovakia No. 27/1920 Coll., establishing a permanent advisory board for tackling alcoholism. 4 | Act No. 64/1918 Coll., on special transitional provisions in Slovakia. 5 Arnold Holitscher, M.D. (7 August 1859-21 October 1942) was a physician in Horní Slavkov and a politician; he was engaged in the anti-alcohol movement and contributed significantly to the drafting and adoption of Act No. 86/1922 Coll. 6| Act. No. 86/1922 Coll., introducing restrictions on the serving of alcoholic beverages 
1 May 1922, this act was the first piece of legislation in what was then Czechoslovakia to govern the domain of alcoholic beverages. Its major benefits included its clear definition of the term "alcoholic beverage" and the determination of the age limit for consuming alcoholic beverages; beer and wine, including fruit wine, were allowed to be served to people above 16 years of age, while other types of alcoholic beverages could be served to individuals above 18. More specific implementation of this law was described in a government regulation, ${ }^{7}$ which provided more detailed definitions of the rights and obligations of alcohol dealers. A captivating account of the "battle" for the final version of the Holitscher Act is provided by Jančík (2014) in his study exploring the conflicts between the advocates and opponents of abstinence in Czechoslovakia in the period between the World Wars and, in particular, the significance and power of the alcohol "lobby". The drafts of the Holitscher Act and their discussion were exemplary illustrations of the way in which professional institutions (such as those associating manufacturers of ethyl alcohol and spirits, traders, and innkeepers) could exert influence on the political scene (the Agrarian Party) and hamper any efforts that might endanger their financial proceeds. The First Republic thus learnt a lesson that alcohol-related issues cannot be solved by legal instruments. During the period between the First and Second World Wars no major legislative changes were made in what was then Czechoslovakia that could strengthen anti-alcohol activities on the part of either national or local government institutions and thus facilitate responses to the issue under consideration.

\subsection{Temperance Association}

The Czechoslovak Temperance Association (CTA) was founded in 1922; its statutes were approved by an edict of the Minister of the Interior, No. 75844/22-6, dated 12 October 1922. The CTA was an umbrella organisation for all ${ }^{8}$ the temperance and teetotal associations and clubs in what was then the Czechoslovak Republic (Šejvl \& Miovský, 2018).

Autonomous headquarters were established for different parts of the republic (Bohemian, ${ }^{9}$ Moravian, ${ }^{10}$ Silesian, ${ }^{11}$ and Slovak ${ }^{12}$ ). These were centrally organised by the General Secretariat of the Czechoslovak Temperance Association (Lányi, n.d.).

The Regional Headquarters for Slovakia of the Czechoslovak Temperance Association were established in Bratislava on 17 May 1922, with Prof. Karol Lányi being commissioned

7| Government Regulation No. 174/1922 Coll., implementing the law of 17 February 1922, No. 86 Coll., introducing restrictions on the serving of alcoholic beverages.

8| Regional, district, and local organisations.

9| The Bohemian Headquarters had their offices at the General Secretariat at Riegrovo nábřeží 4, Prague 2.

10| with its registered office at Čechova 42, Brno-Žabovřesky

11 with its registered office in Silesian Ostrava; the exact address has not been identified.

12 | with its registered office at Šafárikovo nám. 2, Bratislava to head it as of 26 January 1923 (Morovicsová \& Falisová, 2016). Its core activities for Slovakia were identical to those pinpointed for the Czech lands. Its four principal tenets remained unchanged: 1) educational, awareness-raising, and cultural events (hosting lectures, educational meetings, and courses for both the general public and the scientific community, education and publication of materials on tackling alcoholism and on alcohol treatment, and medical training); 2) social and hygienic activities (the establishment and management of treatment institutions and counselling centres based on the principles of abstinence, the establishment of inexpensive diners, restaurants, and hotels where no alcohol was served, the establishment of shops selling milk and fruit, and support for the manufacture and distribution of soft drinks); 3) social activities in general (involvement in the improvement of the situation in society and support for institutions advocating temperance), and 4) legal activities (promotion of the adoption of anti-alcohol laws and regulations varying in terms of their legal strength, the legal protection of adolescents and labourers, and the regulation and reduction of the production and sale of spirits in relation to local customers - "the local option") and organisational activities (Šejvl \& Miovský, 2018).

In Bohemia, thanks to the efforts of Břetislav Foustka, Jan Šimsa, Father Bedřich Konařík, and other representatives of the Czechoslovak temperance movement, the first post1918 institutional alcohol treatment was introduced in 1923 in the Tuchlov facility, but in Slovakia there was a long-term lack of an alcohol institution. Nevertheless, pressure for the establishment of such a treatment facility had been apparent since the independent republic was proclaimed in 1918. The idea of fostering the development of institutions which would systematically engage in treating alcohol dependency was considered by the Ministry of Public Health and Physical Education as early as in 1919. The main driving element was the Czechoslovak Temperance Association (CTA), specifically its Regional Headquarters for Slovakia. The Statutes of the Regional Headquarters were endorsed by the Ministry in October 1925. Its founding members included Tomáš G. Masaryk and the Regional Headquarters also enjoyed support from Edvard Beneš.

The activities of the Temperance Association, which also maintained collaboration with the Red Cross, did not lead to any major positive results. Starting from the mid-1920s, in particular, the Association issued a number of publications dealing with the issue of addiction to alcohol. One of the most prolific representatives of the Temperance Association in Slovakia was Karol Lányi, who was especially involved in the production of texts that popularised abstinence and rejected alcohol. These included Alcohol and Morality, How to Tackle Alcoholism, Alcohol and Youth, and Alcohol and the Social Issue.

The most prominent literary attempts at a comprehensive grasp of alcohol-related issues included the Teetotal Temperance Reader by Jurkovič et al. (1935). Generally speaking, this work involved a monograph summarising salient treatises by influential figures in the anti-alcohol move- 
ment in Slovakia. The publication was primarily intended for district anti-alcohol boards and as reference material for awareness-raising lectures on alcohol. The secondary objective of the publication was to help in creating suitable conditions and obtaining financial resources for the establishment of the first alcohol treatment facility in Slovakia. However, it fell short of what had been expected from it in terms of its benefits.

At the opposite end of the spectrum from these teetotal efforts and the activities of the CTA, there were organisations that sought to minimise the effects of alcohol or even tout its benefits for human health. At the national government level, the Czechoslovak Alcohol Commission was a significant player in this respect. ${ }^{13}$ Although it went into private ownership as of October 1922, its main objective remained to secure as much income for the public purse from the taxation of alcohol as possible. As far as private entrepreneurship was concerned, such advocacy entities included the Union of Czech Associations of Licensed Victuallers and Publicans for Bohemia in Prague, "Hostimil", the Central Union of Czechoslovak Catering Services for Bohemia, Moravia, and Silesia, brewery unions, and the Union of Professional Associations to Combat Eccentric Teetotalism (Jančík, 2014).

\section{THE TREATMENT FACILTY AT ISTEBNÉ NAD ORAVOU}

In calling for the establishment of a treatment institution in Slovakia, the absence of any facility of this kind and the complications associated with the provision of such treatment in the only dedicated facility in the country - in Tuchlov - turned out to be a powerful argument presented to the Ministry of Public Health and Physical Education. The barriers to treatment there for patients from Slovakia and Carpathian Ruthenia included the distance and a lack of willingness and knowledge on the part of physicians to refer their patients to such treatment as was covered by the contributory sickness fund.

The strategy used to select the location for the treatment facility followed the requirements for the establishment of alcohol institutions that were applied at the time. It was proposed that it should be not far away from a town, within a reasonable driving distance for a medical doctor, but in a place where it would be possible for the patients to be able to work in the fresh air, both in the fields and in the woods, and for the institution to be partly self-sufficient with regard to food supplies (fruit and vegetables) and firewood in the winter months. Istebné nad Oravou was selected as the place not only met the conditions that were required, but also involved a bargain of a manor house including a fruit orchard,

$\mathbf{1 3}$ | Created on the basis of Resolution of the Czechoslovak National Committee No. 29/1918 Coll., on the establishment of the Czechoslovak Alcohol Commission, dated 8 November 1918, and dissolved on the basis of Decree No. 294/1922 Coll., on the termination of the operation of the Czechoslovak Alcohol Commission, dated 30 September 1922. a field, a forest, a park, two outbuildings, and a joinery shop (Property Lease, 1939). All this matched the requirements for a treatment institution perfectly. The facility was established in a property which the Czechoslovak Temperance Association procured (with support from the ministry, as in the case of the Tuchlov Institution) from Anna Rakovszka in 1937 for CZK 320,000. To demonstrate its teetotal attitudes, the town closed down its only tavern on the occasion of the $555^{\text {th }}$ anniversary of its foundation (1937).

The Regional Headquarters for Slovakia of the Czechoslovak Temperance Association opened the alcohol treatment institution in Istebné nad Oravou, served by the Veličná Post Office, in the Dolný Kubín District, on 2 November 1937 at 10.30 (Regional Headquarters for Slovakia, 1937). Over 250 people were present at the formal opening. The introductory speech was given by Dr. Ladislav Jurkovič, the CTA vice-chair for Slovakia. Salutatory addresses that followed were delivered by representatives of the regional and district authorities, representatives of the Ministry of Public Health and Physical Education headed by Rudolf Homola, Ignác Grebáč Orlov, and the priest from Veličná on behalf of the Catholic Parish Office in Veličná, Peter Halaša and a minister from Veličná on behalf of the Orava Protestant Senior Office, Mikuláš Gacek on behalf of Matica Slovenská (a Slovak national cultural association), the mayor of the municipality. Ondrej Greguška, Jozef Ujček on behalf of the Párnica notarial office, Father Bedřich Konařík on behalf of the Tuchlov treatment facility, Ms. Jurkovičová on behalf of the women's section of the Temperance Association, and Ján Hroboň with the local minister on behalf of the local Protestant Parish Office. Financial contributions to the establishment of the treatment facility were made by the Ministry of Health (at the suggestion of the Czechoslovak permanent advisory board for tackling alcoholism), the Ministry of Welfare, the Provincial Committee, headed by its president Jozef Ország, and many others (Opening, 1937).

The Istebné treatment facility differed from Velké Kunčice and particularly Tuchlov in terms of the target groups they were each intended for. While both the older treatment facilities were intended exclusively for patients addicted to alcohol (with patients diagnosed with concurrent conditions or addicted to other substances being strictly rejected), the Istebné institution was different in this respect. The establishment of the treatment facility resulted from efforts to provide treatment to those who "were deprived by alcoholism of their stamina, had their willpower broken and their enthusiasm for work subdued by alcohol, and were incapacitated for work, temporarily or for good, because of alcohol" (Regional Headquarters for Slovakia, 1937). In addition to treating alcoholics, the institution was also intended to provide treatment to cocaine and morphine addicts.

The capacity of the treatment facility was set at 17 beds. Vladimír Fábry, M.D., from the hospital in Dolný Kubín was appointed as the in-house physician. Emil Kraus was commissioned to manage the facility and provide pedagogical guidance. He had received training from Father Konař́k in Tuchlov and held the same position in Istebné as Koňařík 
in Tuchlov. In addition, his responsibilities included administrative work. Ondrej Medvecký was the caretaker in the facility. He worked there continuously until the early 1950 s.

Morovicsová and Falisová (2016) report that the daily fees in Class III were set at CZK 28.00 and raised to CZK 32.00 if a single room was required. The fee for Class II was set at CZK 45.00, with CZK 25.00 being charged for endowment beds (the latter figure was covered by the Ministry of Public Health). Patients of low socio-economic status were granted a 25-50\% discount. Those who were covered by health insurance offices and members of sickness funds had their stay fully covered in the same way as if they were admitted to a regular hospital (Regional Headquarters for Slovakia, 1937). Financial support was provided by the Ministry of Public Health and Physical Education and the local government, especially by the Dolný Kubín District Authority. In 1938, a subsidy amounting to CZK 3000 was granted (Support, 1938a). The level of financial support was at its greatest in the year of the opening of the treatment facility, and subsequently declined continuously.

The duration of the inpatient treatment was set at five to six months. Entry to treatment involved the same procedures and requirements as was the case in Tuchlov - an initial medical examination, assessment and diagnosis, the determination of treatment and dietary regimens, and patients' permanent abstinence during their stay in the institution. The patients were accommodated in dormitories, but the treatment facility also possessed a communal room, dining room, library, caretaker's office, and areas where hydrotherapy and baths took place. The areas intended for work therapy were situated in the grounds adjacent to the facility.

Whether the property that had been purchased was suitable for treatment purposes is questionable, given its physical condition. There was no running water in the building at the time when treatment began to be provided there. Water had to be brought in from a well by the patients or the staff.
This made it difficult to meet basic sanitary requirements and provide hydrotherapy, which was to be an integral part of the treatment. The building had no electricity supply or central heating, either (Morovicsová \& Falisová, 2016).

The frequency of the audits of the treatment facility performed by the Dolný Kubín District Authority officials and some of their results are summarised in Table 1.

The inspection visit carried out by the Dolný Kubín District Authority officials on 19 January 1939 found that there were two patients and that the ordinary operation of the treatment facility was problematic (Record, 1939a). During the era of the Slovak State (1939-1945) the facility kept running, although the available historic records do not provide enough evidence to determine how many patients sought treatment there at that time.

To this day, it is not clear when the treatment facility effectively closed down. Morovicsová and Falisová (2016) report that the activities of the institution were wound up for two main reasons: a lack of funds and the separation of the Slovak Temperance Association from the Czechoslovak Temperance Association as a result of the breakup of the republic in the aftermath of the Munich Agreement and the proclamation of the independent Slovak State. This is believed to have taken place some time in 1939. Such a conclusion was probably inferred from the audit report of 6 May 1939, which indicated that the treatment facility had terminated its activities as of 15 April 1939 (Record, 1939b). It is not clear why this entry was included in the book of records, as other materials indicate otherwise.

Interestingly enough, this information does not correspond with the archival materials that were recovered from the Dolný Kubín District Archives. On 19 January 1939, an audit was carried out in the facility and found that there were two patients, the regular operation of the facility was not possible, as the water pipes in the building froze in winter be-

\begin{tabular}{|c|c|}
\hline Date of audit & Evaluation \\
\hline 31 January 1938 & $\begin{array}{l}\text { The institution has not yet been furnished with the equipment needed to provide treatment. The main issue is the } \\
\text { water supply - water must be brought in from a nearby well. The bathroom fixtures are very basic and make it } \\
\text { impossible to perform hydrotherapeutic procedures to the extent needed. Both the kitchen and the dormitories are } \\
\text { clean. Although also clean, the toilets are very primitive, with no flushing. At the time of the audit, there were six } \\
\text { inpatients; they are happy and their physical condition is improving (Record, 1938d). }\end{array}$ \\
\hline 29 April 1938 & $\begin{array}{l}10 \text { patients hospitalised - they are very satisfied with their stay in the institution. The building of a water closet, } \\
\text { washroom, and hydrotherapy room was initiated. The kitchen and the food store were in exemplary order. } \\
\text { Accommodation and food for the patients are satisfactory (Record, 1938c). }\end{array}$ \\
\hline 13 July 1938 & $\begin{array}{l}12 \text { patients hospitalised - they are all satisfied with the treatment and their health is improving. Water piping, water } \\
\text { closets, showers, and hydrotherapy facilities have been installed in the building. The dormitories, kitchen, and } \\
\text { food store were found to be kept exemplarily clean. The accommodation and food for the patients are satisfactory } \\
\text { (Record, 1938b). }\end{array}$ \\
\hline 23 July 1938 & $\begin{array}{l}\text { Five patients hospitalised - they are all satisfied with the treatment, their physical condition is satisfactory } \\
\text { (Record, 1938a) }\end{array}$ \\
\hline
\end{tabular}

Table 1 | Selected conclusions from audits performed in the Istebné nad Oravou institution 
cause of the low temperatures, and the hydrotherapy room had not been properly equipped. On the other hand, the rooms for patients were well equipped (Record, 1939a).

The above materials reveal that on 21 April 1939 the property as a whole was let to its caretaker Ondrej Medvecký (Property Lease, 1939). The inspection conducted on 6 May 1939 reported 15 inpatients (nine men and six women). On paper, the treatment facility existed as late as in 1945; while it is probable that no treatment was being provided at that time, it still reported employees. On 19 May 1947 the entire property of the treatment facility belonging to the Slovak Temperance Association was formally handed over to the Health Commission. This transaction was based on a donation agreement between the Slovak Temperance Association and the Health Commission dated 27 February 1947 (Record, 1947; Handover of Teetotal Institution, 1947). As a result, the treatment facility changed its legal status from an independent establishment of the Czechoslovak Temperance Association (or the Slovak Temperance Association, to be exact) to the National Alcohol Treatment Institution. The facility continued to operate and appeared to provide treatment services to patients, as indicated by an application for admission to treatment filed by a postal worker on 30 September 1948 (Treatment Application, 1948) and correspondence exchanged between the institution and the Health Commission concerning the endorsement of a certificate needed for the issue of food vouchers and instructions regarding construction works in November 1948 (Health Commission, 1948). At that time the alcohol institution was incorporated into the national health system (Consumption Receipt, 1948). On paper, in the first half of 1949 the treatment facility was still in operation; the existence of its employees is documented by a receipt showing the payment of insurance for the employees of the institution (Receipt, 1949). In effect, the treatment facility was closed down in December 1949. The last employment contract was terminated as of 1 October 1949 (Overpayment, 1950). On Monday 5 December 1949 the caretaker of the institution advised the Health Commission in writing of the amount needed to repair a damaged railing (Damaged Railing, 1949), and on Thursday 8 December 1949 a record of the inventory of the former teetotal institution in Istebné nad Oravou was made, under the institutional reference number 117/1949 (Items of Inventory, 1949).

By January 1950 the former manor housed the Regional Children's Home (Bill, 1950).

\section{DISCUSSION AND CONCLUSION}

The establishment of the treatment institution in Istebné nad Oravou involved some distinctive features which differed from two earlier treatment facilities which came into existence in the $20^{\text {th }}$ century in what was then Czechoslovakia. Despite some variations in the level of formal social acceptance of alcoholism (with Slovakia being more tolerant towards excessive drinking than Bohemia or Moravia) and treatment focus, together with Velké Kunčice and Tuchlov, this treatment institution constituted logical solid foundations from which Jaroslav Skála and his colleagues could draw inspiration in 1948 when developing what is referred to as the "Apolinar Model" (Skála, 1957). In addition to patients dependent on alcohol, the treatment facility took in patients addicted to morphine and cocaine, which made it exceptional and different from the Velké Kunčice and Tuchlov institutions, as those accepted only alcohol-dependent patients. In spite of this, the Istebné facility never reached full occupancy and, with the exception of the first two years of its existence (1937-1939), faced a significant lack of financial resources needed to cover the treatment of its patients, but also its day-to-day operation and equipment. A factor that played a major role in this respect was the breakup of Czechoslovakia and the establishment of the independent Slovak State on 14 March 1939. This meant the discontinuation of financial support - modest as it was - for those not covered by health insurance (endowment beds), as well as the split of the Czechoslovak Temperance Association and cuts in (effectively, the elimination of) subsidies from the government. It is noteworthy that the Velké Kunčice institution had to close down because of the Great War (1915), the Tuchlov institution ceased to operate after the Sudetenland was handed over to the German Reich (1938), and the operation of the treatment facility in Istebné nad Oravou was dramatically reduced as a result of the breakup of the republic (1939). Despite many difficulties, the institution continued to operate, albeit pro forma, in the subsequent years. It acted as an entity managed by the Slovak Temperance Association not only during the existence of the Slovak State, from 14 March 1939 to 3 May 1945, but also in the years that followed this period.

Its establishment, initiated primarily by the CTA, was driven by the idealistic or virtually utopian notion of bringing the "Czechoslovak nation" to sobriety. Even then it must have been clear to all the public policy makers and public health stakeholders that such goals could not be achieved in this manner. Morovicsová and Falisová (2016) suggest that the efforts to reform society as regards excessive alcohol use and drinking-related habits did not match the opinions and values of the individual population groups. Moreover, the CTA offered those who were expected to give up alcohol no reasonable and acceptable alternative that could help them deal with their social and economic problems. The economic situation of the population - both in Austria-Hungary and the new republic - was far from ideal and alcohol worked as a panacea for a significant segment of society. The majority of society, across all walks of life, showed a largely indifferent attitude towards the teetotal efforts and the ambition to make the entire nation opt for sobriety. The retailers, largescale entrepreneurs, and landowners who profited from the manufacturing and sale of alcohol generated a counterpressure to these efforts which made them a major behind-the-scenes political force. Additionally, the nationwide abstinence philosophy and campaigns featured sarcastic and moralising elements, with targeted rational education aimed at specific groups of society being rather exceptional. In summary, people were presented with the opinions of a relatively limited segment of the population and, more- 
over, in a situation in which few of them felt that addiction to alcohol might be of any concern to them.

The attitude of resistance on the part of some physicians should also be mentioned. In a better case, they were not interested in alcohol-related issues and did not regard alcoholics as ill and alcoholism as an illness. In a worse case, they recommended moderate drinking as a cure for various conditions. Systematic aftercare helping patients with recovery after their discharge from institutional treatment and providing support for their families was limited.
Despite all these facts, it is beyond doubt that institutional addiction treatment in Istebné nad Oravou played an important role in the development of treatment approaches after 1948. It built and drew on the experience from the Velké Kunčice and Tuchlov treatment facilities, its staff sought inspiration from the Tuchlov approach, in particular, which had become well established by that time, and the involvement of Father Bedřich Konařík and Jan Šimsa in the preparation of the treatment approach was undoubtedly a significant factor. Finally, its existence made it possible to draw formal attention to the risks of addiction to morphine and cocaine and to raise the issue of the treatment of such addictions being covered by health insurance, a practice which was very rare in what was then Czechoslovakia.
Authors' contributions: Jaroslav Šejvl searched and processed the historical documents and subsequently categorised them according to their mutual thematic relationships in terms of their origin, content, and development, drafted the article, and finalised it. Miroslava Mašlániová was involved in the processing and analysis of historical documents. Michal Miovský reviewed the thematic relationships between the categorised documents and participated in the drafting of the article and its finalisation.
Declaration of interest: No conflict of interests.

\section{REFERENCES}

Beneš, E. (1915). Problém alkoholové výroby a abstinence [The Issue of Alcohol Production and Abstinence]. Praha: Nákladem Československého abstinentního svazu

Bill (1950). A bill for the Regional Children's Home in Istebné nad Oravou, dated 9 January 1950, without a reference number. Dolný Kubín District Archives: Call No. 137.

Certificate (1949). Dolný Kubín District National Insurance Company - payments of employee contributions for I-II 1949, Istebné n/Or. Teetotal Institution, dated 9 March 1949, Ref. No. 70/1949. Dolný Kubín District Archives: Call No. 137.

Chisholm H. ed. (1911). "Mathew, Theobald”, Encyclopaedia Britannica. 17. (11th ed.). New York: Encyclopaedia Britannica.

Consumption Receipt (1948). Počítací stroj zn. Albona, štátný liečebný ústav pre alkoholikov v Istebnom n/Or., zo dňa 17. 11. 1948, č.j. 57/1948 [Albona calculating machine, national alcohol treatment institution in Istebné nad Oravou, dated 17 November 1948, Ref. No. 57/1948]. Dolný Kubín District Archives: Call No. 137.

Damaged Railing (1949). Dopis Štátného liečebného ústavu alkoholikov $\checkmark$ Istebnom n/Oravou Povereníctvu zdravotníctva ohladne poškodeného zábradlia, zo dňa 5. 12. 1949, č.j. 111/1949. [A letter from the national alcohol treatment institution in Istebné nad Oravou to the Health Commission concerning a damaged railing, dated 5 December 1949, Ref. No. 111/1949]. Dolný Kubín District Archives: Call No. 137.

Dolnozemský Slovák (15 April 1913). Ked'sa pije od dlhej chvíle! [When Drinking is a Way of Killing Time] XI (4), 31-32.

Duka-Zólyomi, N. (2015). Prvé hnutie striedmosti na Slovensku v XVI. storočí [The First Temperance Movement in Slovakia in the $16^{\text {th }}$ Century]. Akoholizmus a drogové závislosti (protialkoholický obzor), 50 (5), 251-255.

Ferjenčík, J. (2010). Úvod do metodologie psychologického výzkumu [Introduction to Psychological Research Methodology]. Praha: Portál.

Fülöp, S. (1903). Az Alkoholizmusról. Budapest.

Gergelyi, 0. (1973). Z dejín boja proti alkoholizmu [From the History of Fighting Alcoholism]. Výživa a Zdravie, 18(10), 226-227.
Handover of Teetotal Institution (1947). A notice of the Slovak Temperance Association to Mr. Ondrej Medvecký about the handover of the inventory of the Teetotal Institution to the representatives of the Health Commission and the nationalisation of the treatment facility, dated 26 April 1947, Ref. No. 108/1947. Dolný Kubín District Archives: Call No. 137

Health Commission (1948). Liečebný ústav v Istebnom nad Oravou - opravné práce; ze dne 6. 11. 1948, č.j. 224-17455/1948 [Treatment institution in Istebné nad Oravou - repair works; dated 6 November 1948, Ref. No. 224-17455/1948]. Dolný Kubín District Archives: Call No. 137.

Items of Inventory (1949). Odpis zápisnice o inventári bývalej abst. Ličebne $v$ Istebnom, zo dňa 8. 12. 1949, č.j. 117/1949 [Copy of the record of the inventory of the former teetotal institution in Istebné, dated 8 December 1949, Ref. No. 117/1949]. Dolný Kubín District Archives: no call number.

Jančík, D. (2014). "Pít či nepít - to jest, oč tu běží." Střety příznivců a odpưrců abstinence v meziválečném Československu ["To Drink or not to Drink - That is the Question." Struggles of the supporters with the opponents of teetotalism in interwar Czechoslovakia]. Historická sociologie/Historical Sociology, 1, 47-69. https://nbn-resolving.org/urn:nbn:de:0168-ssoar-406522

Jurkovič, L., Čárský, J., Čobrdu, P. V., Matzenauer, J., Vlasák, G. \& Procházka, A. (1935). Abstinentná protialkoholná čítanka [Teetotal Temperance Reader]. Bratislava: Regional Headquarters for Slovakia, Czechoslovak Temperance Association.

Krestan (1912). Slávnost' antialkoholistov [Feast of Teetotallers] No. 1, Vol. 13

Lányi, K. (n.d.). Alkohol a mravnost'[Alcohol and Morality]. Bratislava: Regional Headquarters for Slovakia, Czechoslovak Temperance Association.

Mareš, A. (1981). Historie lidového abstinentného hnutí na Slovensku - historie abstinentního hnutí v Československu - část III [A History of the Popular Temperance Movement in Slovakia - A History of the Temperance Movement in Czechoslovakia - Part III]. Archives of the National Museum in Prague, Call No. 1.

Miles, M. B., \& Huberman, A. M. (1994). Qualitative data analysis: An expanded sourcebook. London: Thousand Oaks, New Delhi: SAGE Publications. 
Miovský, M. (2006). Kvalitativní př́stup a metody v psychologickém výzkumu [Qualitative Approach and Methods in Psychological Research]. Praha: Grada a.s.

Morovicsová, E. \& Falisová, A. (2016). Význam protialkoholických liečební v boji proti alkoholizmu v prvej Československej republike [The Importance of Anti-alcohol Treatment Institutions for the Fight against Alcoholism in the first Czechoslovak Republic]. Česká a Slovenská psychiatrie, 112 (6), 287-297.

Národný hlásnik (20 March 1904). Najkrajší výsledok tohoročnej porady slovenskej mládeže [The Greatest Outcome of This Year's Meeting of Slovak Youth], Vol. 33, No. 1, p. 4.

Opening (1937). Istebné. Teetotal Institution. Opening, record dated 20 November 1937, Ref. No. 339.132/11-1937. Dolný Kubín District Archives, Call No. 882/1937

Overpayment (1950). Andrej Medvecký, bývalý domovník ústavu v Istebnom n/0, preplatok, zo dňa 16. 4. 1950, č.j. 141-23061/1949. [Andrej Medvecký, a former caretaker of the institution in Istebné nad Oravou, overpayment; dated 16 April 1950, Ref. No. 141-23061/1949]. Dolný Kubín District Archives: Call No. 137.

Plichtová, J. (1996). Obsahová analýza a jej možnosti využitia v psychológii [Content Analysis and the Possibilities of Its Use in Psychology]. Čs. psychologie 4 (40), 304-314.

Podjarovský (1901) Ako môže učitel' odhovorit' občanov od pijatiky [How a Teacher Can Discourage Citizens from Drinking]. Rodina a škola 3(5), 75-77.

Pokrok (12 March 1904), No. 2, Vol. II, Alkohol a mlieko [Alcohol and Milk], p. 11.

Property Lease (1939). Management of the Teetotal Institution in Istebné n. O. - property lease, dated 21 April 1939, Ref. No. 364/1939. Dolný Kubín district Archives: Call No. 137.

Record (1938a). Record of Audit Conducted on 23 July 1938 in the Istebné Alcohol Treatment Facility, No. 11.330. Dolný Kubín District Archives - Health Department 7959/1938.

Record (1938b). Record of Audit Conducted on 13 July 1938 in the Istebné Alcohol Treatment Facility, No. 7788. Dolný Kubín District Archives - Health Department 7959/1938.

Record (1938c). Record of Audit Conducted on 29 April 1938 in the Istebné Alcohol Treatment Facility, No. 4906. Dolný Kubín District Archives - Health Department 7959/1938.

Record (1938d). Record of Audit Conducted on 31 January 1938 in the Istebné Alcohol Treatment Facility, No. 1502. Dolný Kubín District Archives - Health Department 7959/1938.

Record (1939a). Record of Audit Conducted on 19 January 1939 in the Istebné Alcohol Treatment Facility, No. 21/1939. Dolný Kubín District Archives: Call No. 882/1937.

Record (1939b). Record of Audit Conducted on 6 May 1939 in the Istebné Alcohol Treatment Facility, No. 21ad/1939. Dolný Kubín District Archives: Call No. 882/1937.

Record (1947). Prevzatie inventáru a majetkovej podstaty v Istebnom - record dated 19 May 1947. Dolný Kubín District Archives: Call No. 137.

Regional Headquarters for Slovakia (1937) Krajinské ústredie pre Slovensko Čsl. Abstinentného sväzu v Bratislave - odporúčanie abstinentnej liečebně; ze dne 16. nov. 1937, č.j.: 1399/37 [Regional Headquarters for Slovakia, Czechoslovak Temperance Association - recommendation to the teetotal treatment facility; dated 16 November 1937, Ref. No.: 1399/37]. Dolný Kubín District Archives: Call Number 137.

Sedlák, P. (1998). Hnutie spolkov striezlivosti na Slovensku v rokoch 1844-1874 [The Movement of Temperance Associations in Slovakia from 1844 to 1874]. Prešov: Michal Vašek Publishers.

Skála, J. (1957) Alkoholismus [Alcoholism]. Praha: Státní zdravotnické nakladatelství. Support (1938a). Dolný Kubín District Authority - Application for Support for the Istebné Teetotal Institution, dated 27 April 1938, Ref. No. 3613/1938. Dolný Kubín District Archives: clerk 3613/1938.
Šejvl, J. \& Miovský, M. (2017). Nejstarší specializované lůžkové zařízení pro léčbu závislosti na alkoholu na historickém území Čech a Moravy: prípadová studie protialkoholní léčebny ve Velkých Kunčicích (1911-1915) [The first specialised residential treatment institution and programme for alcohol-related problems in the historical area of Bohemia and Moravia: case study of the residential alcohol programme in Velke Kunčice (1911-1915)]. Adiktologie, 17(2), 134-146.

Šejvl, J. \& Miovský, M. (2018). The First Inpatient Alcohol Treatment Facility in the Czech Republic: case study of the Tuchlov institution (1923-1938). Adiktologie, 18(2), 97-104.

Treatment Application (1948). Pavol Roháček - pošt. zriadenec - žiadost o liéčbu zo dňa 30. 9. 1948. [Pavol Roháček - a postal worker - application for treatment dated 30 September 1948]. Dolný Kubín District Archives: Call No. 137.

Winskill, P. T. (1892). The temperance movement and its workers. A record of social, moral, religious, and political progress. London, Glasgow, Edinburgh, and New York: Blackie \& Son, Limited.

Zsigmond, Z. (1906). Szeszfőzés gyümölcsökből borból és a borkészítés melléktermékeiből. Kassán: Vitéz A. Gazdasági Szakkönyvkereskedése.

Act No. 64/1918 Coll., on special transitional provisions in Slovakia.

Act No. 68/1870 of the Imperial Criminal Code, providing for the organisation of the public health service.

Act. No. 86/1922 Coll., introducing restrictions on the serving of alcoholic beverages.

Act No. 96/1929 Coll., annulling Statutory Article XXV/1899 concerning public revenue from the drawing of beverages and Section 11 of Act No. 64 Coll. on special transitional provisions in Slovakia and amending the Trade Licensing Act for the territory of Slovakia and Carpathian Ruthenia.

Government Regulation No. 174/1922 Coll., implementing the law of 17 February 1922, No. 86 Coll., introducing restrictions on the serving of alcoholic beverages.

Regulation of the Government of the Republic of Czechoslovakia No. 27/1920 Coll., establishing a permanent advisory board for tackling alcoholism. 